\title{
Recent advances in understanding hereditary spastic paraplegias and emerging therapies
}

\author{
Pauline Lallemant-Dudek ${ }^{1}$ Frederic Darios ${ }^{1}$ Alexandra Durr (iD) $1,2^{*}$ \\ ${ }^{1}$ Paris Brain Institute (ICM), Inserm U 1127, CNRS UMR 7225, Sorbonne Université, Paris, France \\ ${ }^{2}$ Assistance Publique-Hôpitaux de Paris (AP-HP), Genetic Department, Pitié-Salpêtrière University Hospital, Paris, France
}

\begin{abstract}
Hereditary spastic paraplegias (HSPs) are a group of rare, inherited, neurological diseases characterized by broad clinical and genetic heterogeneity. Lower-limb spasticity with first motoneuron involvement is the core symptom of all HSPs. As spasticity is a syndrome and not a disease, it develops on top of other neurological signs (ataxia, dystonia, and parkinsonism). Indeed, the definition of genes responsible for HSPs goes beyond the 79 identified $S P G$ genes. In order to avoid making a catalog of the different genes involved in HSP in any way, we have chosen to focus on the HSP with cerebellar ataxias since this is a frequent association described for several genes. This overlap leads to an intermediary group of spastic ataxias which is actively genetically and clinically studied. The most striking example is $S P G 7$, which is responsible for HSP or cerebellar ataxia or both. There are no specific therapies against HSPs, and there is a dearth of randomized trials in patients with HSP, especially on spasticity when it likely results from other mechanisms. Thus far, no gene-specific therapy has been developed for HSP, but emerging therapies in animal models and neurons derived from induced pluripotent stem cells are potential treatments for patients.
\end{abstract}

\section{Keywords}

Spastic paraplegia, cerebellar ataxia, spasticity

\section{Peer Review}

The peer reviewers who approve this article are:

1. Craig Blackstone, Neurogenetics Branch, National Institute of Neurological Disorders and Stroke, National Institutes of Health, Bethesda, MD, USA

Competing interests: No competing interests were disclosed.

2. Marcondes Cavalcante França Jr, Department of Neurology, University of Campinas (UNICAMP), Campinas, Brazil Competing interests: No competing interests were disclosed. 
*Corresponding author: Alexandra Durr (alexandra.durr@aphp.fr)

Competing interests: The authors declare that they have no competing interests.

Grant information: The work was supported by funding from Société Française de Médecine Physique et de Réadaptation (PL-D) and Société Francophone d'Études et de Recherche sur le Handicap de l'Enfance (PL-D).

The funders had no role in study design, data collection and analysis, decision to publish, or preparation of the manuscript.

Copyright: $\mathbb{C} 2021$ Durr A et al. This is an open access article distributed under the terms of the Creative Commons Attribution License, which permits unrestricted use, distribution, and reproduction in any medium, provided the original work is properly cited.

How to cite this article: Lallemant-Dudek P, Darios F and Durr A. Recent advances in understanding hereditary spastic paraplegias and emerging therapies. Faculty Reviews 2021 10:(27) https://doi.org/10.12703/r/10-27

Published: 10 Mar 2021, Faculty Reviews 10:(27) https://doi.org/10.12703/r/10-27 


\section{Introduction}

Hereditary spastic paraplegias (HSPs) are a group of rare, inherited, neurological diseases characterized by broad heterogeneity in terms of both their clinical manifestations and genetic causes. HSPs are characterized by degeneration of the corticospinal tract, predominantly of the first motoneuron alone but often involving the second motoneuron ${ }^{1}$. The main symptom is progressive bilateral lower-limb spasticity as a component of pyramidal syndrome.

Pyramidal syndrome is largely a component of more frequently occurring neurological diseases, such as progressive forms of multiple sclerosis or slowly evolving forms of amyotrophic lateral sclerosis, often resulting in delayed genetic diagnosis of $\mathrm{HSP}^{2}$. Without genetic diagnoses, it is difficult to establish the prevalence of HSP. The estimated prevalence based on genetic or clinical diagnoses (or both) from a recent Swedish study is 2.4 out of $100,000^{3}$. This prevalence is near those found in a previous international literature review (2.2 out of 100,000$)^{4}$ and a Portuguese population-based study (4.1 out of 100,000$)^{5}$. One meta-analysis included 13,570 patients with a genetic diagnosis of the most frequently occurring genes (SPAST, REEP1, ATL1, SPG11, SPG15, SPG7, SPG35, SPG54, and $S P G 5)^{6}$. Unsurprisingly, SPG4/SPAST-HSP represents the most frequent overall $(25 \%)^{6}$ as an autosomic dominant transmission, followed by REEP1 and ATL1. The most common autosomic recessive form is $S P G 11$. The relative prevalences vary greatly among populations. The frequency of each gene is influenced by the degree of consanguinity (autosomic recessive bias according to the population screened) and the existence of a founder effect. Furthermore, multilocus and multigenic inheritance as in inherited axonopathies could be the underlying genetic cause, resulting in complex transmission patterns that are more difficult to be recognized ${ }^{7}$.

SPG4/SPAST-HSP is characterized by extreme inter- and intrafamilial variability for the age at onset, ranging from birth to the eighth decade, based on recently updated data following analysis of the world's largest SPG4/SPAST-HSP patient cohort $(\mathrm{n}=842)^{8}$. Analysis of this large cohort made it possible to firmly establish a bimodal distribution for the age at onset for SPG4/SPAST-HSP, and a first major peak occurs before 10 years of age and a second smaller peak occurs between the third and fifth decades. Furthermore, such bimodality reflected the nature of the SPAST causative variants. Indeed, missense variant carriers were characterized by disease onset that was significantly earlier than those of truncating variant carriers. This highlighted, for the first time, a clear genotype-phenotype correlation $^{8}$. Intrafamilial variation of the age at onset due to the same shared causative SPAST variant has yet to be unraveled and is most likely due to genetic or environmental modifiers (or both). To date, SPAST Exon 1 variant c.131C $>$ T/p.(Ser44Leu) appears to be the most well-documented SPG4/SPAST-HSP genetic modifier, leading to marked lowering of the age at onset when carried in combination with a major pathogenic SPAST mutation ${ }^{9,10}$
The age-at-onset phenotype appears to be narrower for other HSP types. SPG3A/ATL1-HSP, the second most frequent dominant HSP, nearly always begins before the age of five years. Both SPG4/SPAST-HSP and SPG3A/ATL1-HSP are purely pyramidal and are associated with considerable sensory loss at the ankles in the former. The distribution of the age at onset for relatively frequent autosomal recessive forms of HSP is narrower, such as that described for SPG11, which represents 8 to $18 \%$ of HSP cases ${ }^{6}$ and has an early onset (before 10 years of age).

What genes are considered to be responsible for HSP? Certainly, more than simply the $S P G$ genes. In a recent review, $79 S P G$ genes were identified ${ }^{11}$. Cerebellar ataxia is often associated, leading to an individualized group of spastic ataxias. There is a definite overlap between the two disease groups, both clinically and genetically ${ }^{12}$.

\section{Spastic ataxias}

The most striking example for overlap between HSP and ataxias is SPG7. The first description was based on two Italian pure-HSP families and one French family, which included three sisters with a pure spastic phenotype on examination, but showing a more complex disease upon imaging and fundus examination, with cerebellar atrophy and optic atrophy ${ }^{13}$. Paraplegin, encoded by $S P G 7$, is a member of the AAA (ATPases associated with a variety of cellular activities) protein family, which is localized to the inner mitochondrial membrane ${ }^{14,15}$. Paraplegin assembles with AFG3L2 (SCA28) to form the oligomeric mitochondrial AAA protease complex, which is involved in protein maturation and degradation ${ }^{16-21}$. Interestingly, SPG7 has been shown to be causative for up to $19 \%$ of undiagnosed cerebellar ataxias ${ }^{22,23}$. We were able to analyze the largest SPG7 cohort (241 patients), assembled through the European SPATAX network (https://spatax.wordpress.com/). We explored genotype-phenotype correlations in this cohort. We found that patients with loss-of-function variants have a more complicated phenotype, with spasticity. On the contrary, patients carrying at least one Ala510Val variant showed more frequent cerebellar ataxia and later onset ${ }^{24}$. Although cerebellar atrophy is known to be a hallmark of $S P G 7$, a specific pattern of gray matter cerebellar atrophy that affects long-distance regions of the brain was recently shown to be associated with cognitive and social-ability impairment ${ }^{25}$. SPG7 is not the only SPG associated with cerebral atrophy.

Aside from SPG7, there are other examples of overlap between cerebellar ataxia and spastic paraplegias (Table 1). Among polyglutamine expansion spinocerebellar ataxias, which share a mutational mechanism with other polyglutamine expansion diseases, such as Huntington disease and spinal bulbar muscular atrophy, the presence of spasticity is very common ${ }^{26}$. The presence of a pyramidal syndrome is linked to the size of the CAG repeat expansion. The longer the CAG repetition is, the more important the spasticity is in addition to the cerebellar ataxia. Neuropathological features showed the involvement of the 


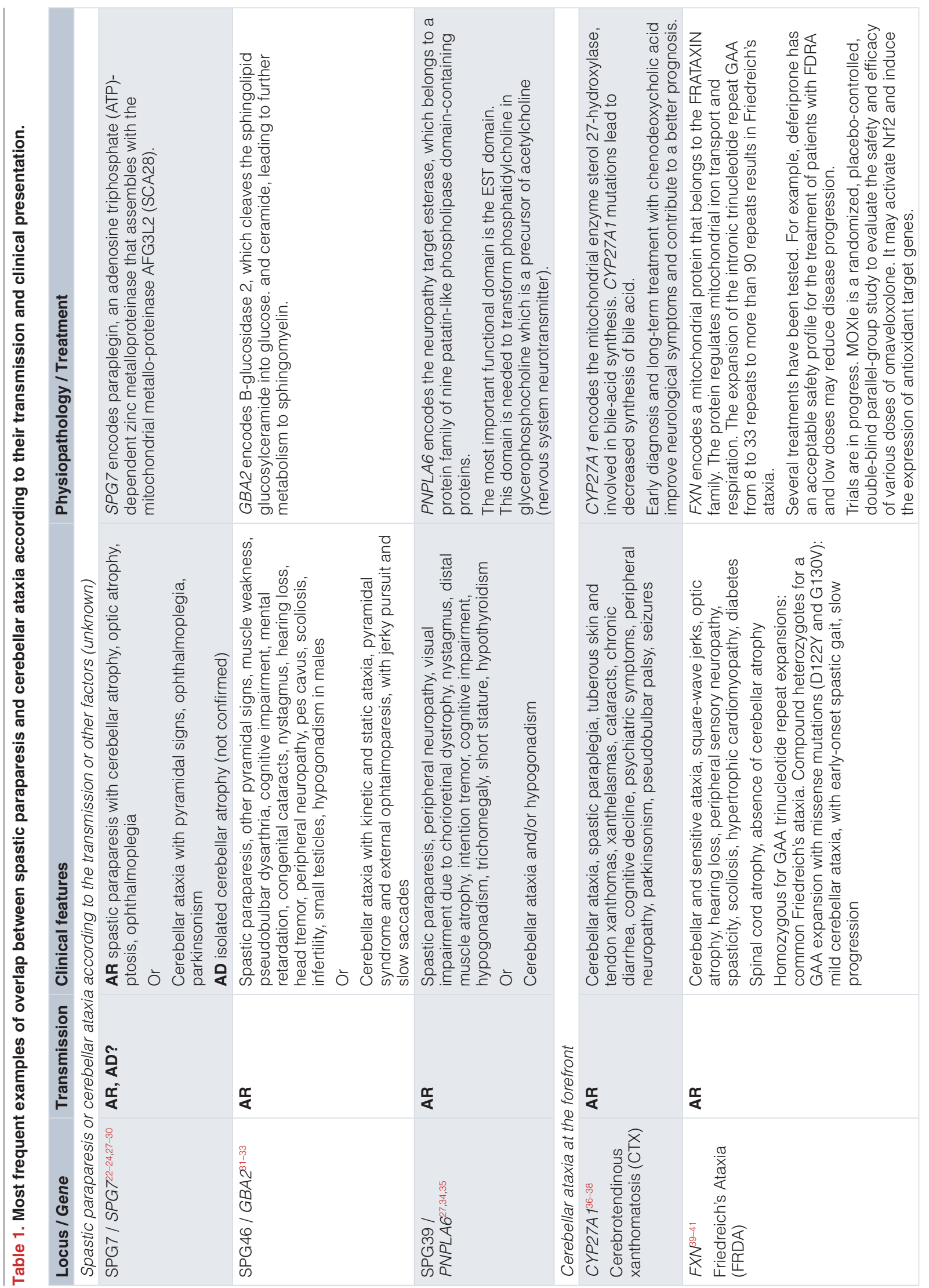




\begin{tabular}{|c|c|c|c|c|c|c|c|c|c|c|}
\hline & 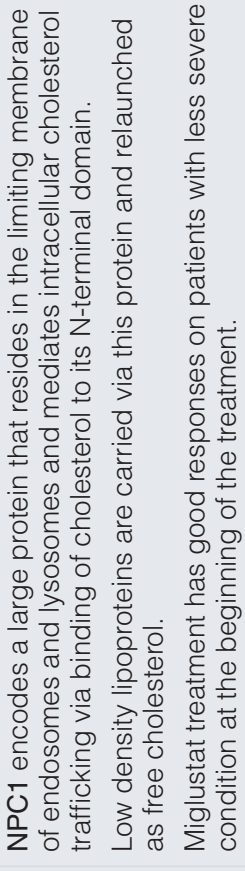 & 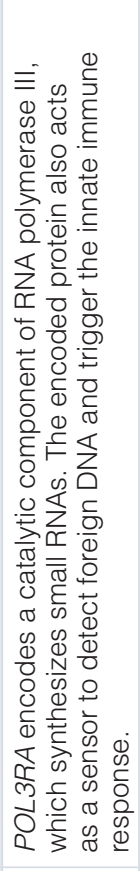 & 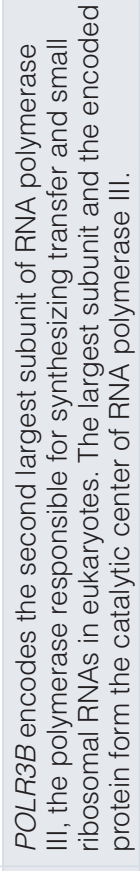 & 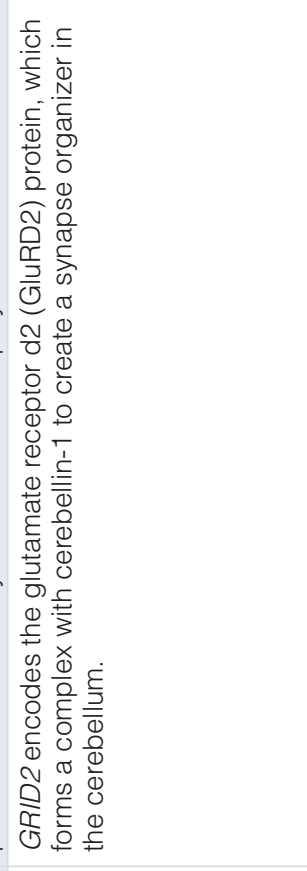 & 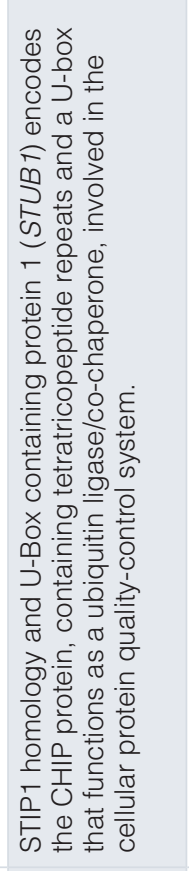 & 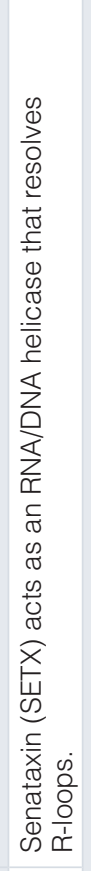 & 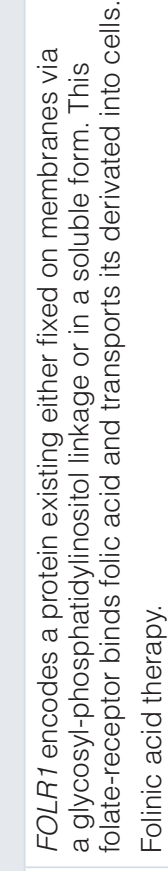 & 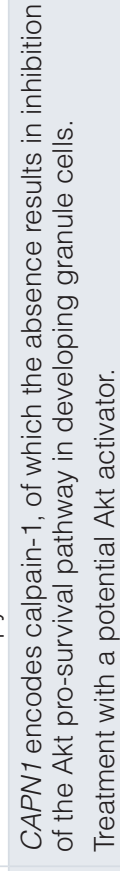 & 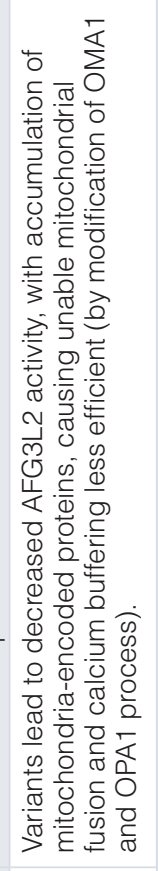 & 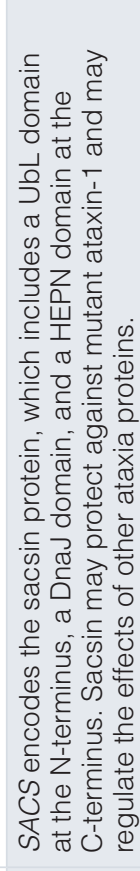 \\
\hline . & 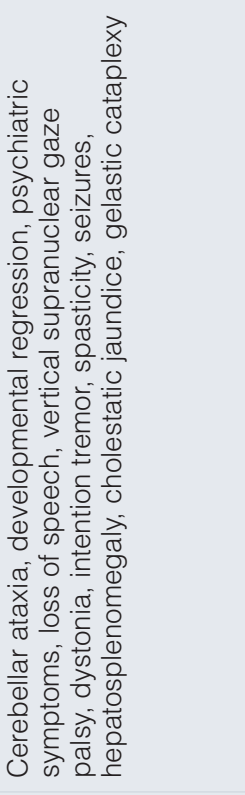 & 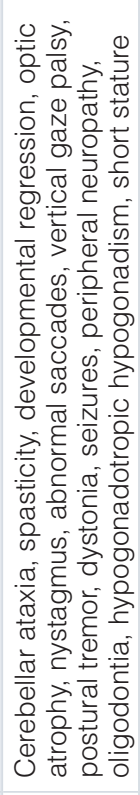 & 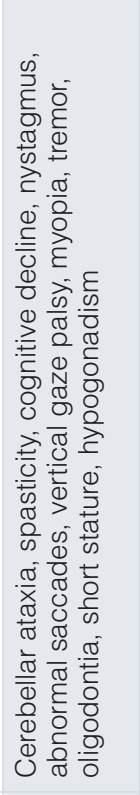 & 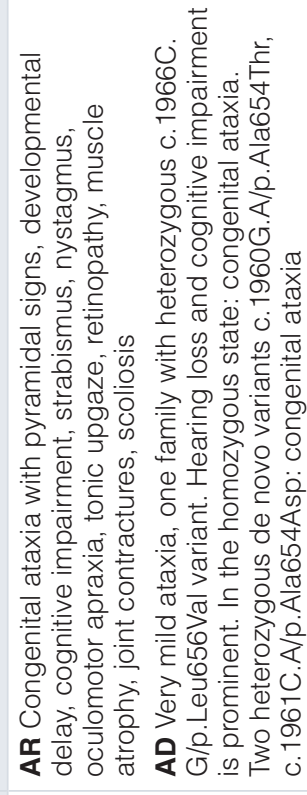 & 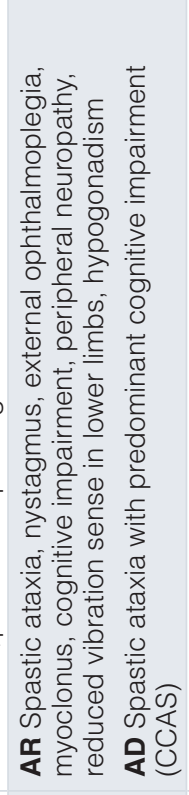 & 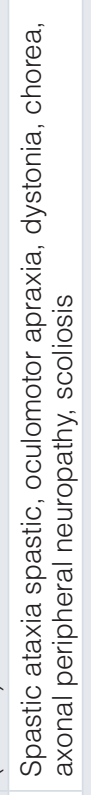 & 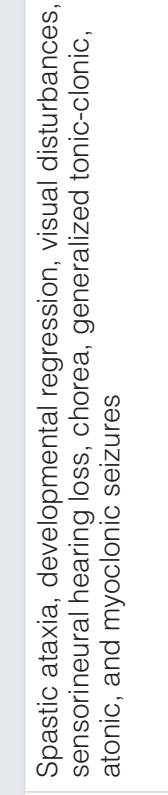 & 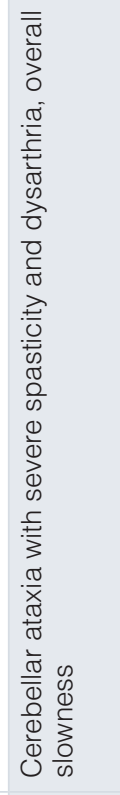 & 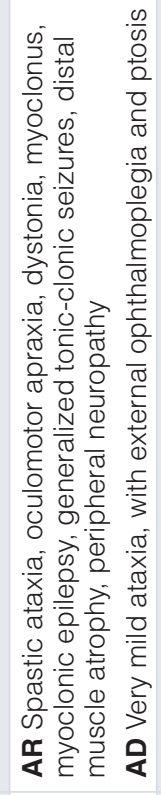 & 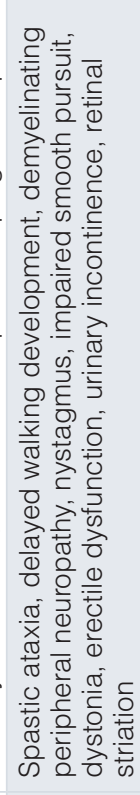 \\
\hline 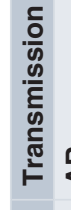 & 这 & $\frac{x}{\alpha}$ & $\frac{\dddot{\pi}}{<}$ & 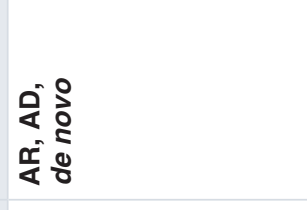 & $\begin{array}{l}\frac{0}{4} \\
\frac{\tilde{c}}{4}\end{array}$ & $\frac{\mathrm{rr}}{\alpha}$ & $\frac{\pi}{<}$ & $\frac{\underline{r}}{<}$ & $\begin{array}{l}\frac{0}{4} \\
\frac{0}{4}\end{array}$ & $\frac{\pi}{\alpha}$ \\
\hline 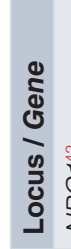 & 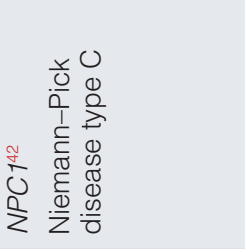 & $\begin{array}{l}0 \\
0 \\
0 \\
0 \\
0 \\
0 \\
0\end{array}$ & & 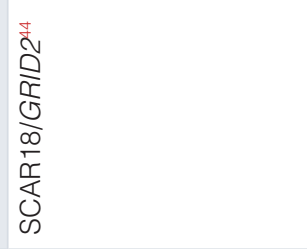 & 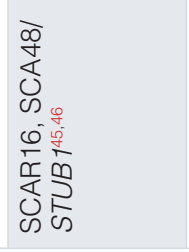 & 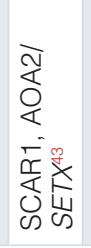 & & $\begin{array}{l}2 \\
0 \\
0 \\
0 \\
0 \\
0 \\
0 \\
0 \\
0\end{array}$ & 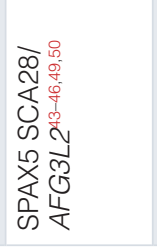 & 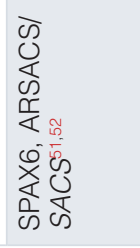 \\
\hline
\end{tabular}


upper and lower motor neurons (that is, the corticospinal tracts or the anterior horn degeneration in SCA1, 2, 3, and 7 or both) ${ }^{53}$.

Like SPG7, mutations in GBA2 and PNPLA6 can result in either spastic paraplegia or cerebellar ataxia with an autosomal recessive transmission mode ${ }^{31-34}$. Other genes have been identified to promote diseases characterized by cerebellar ataxia with spasticity. Eight are known, such as Cerebrotendinous xanthomatosis, Friedreich's ataxia, and Niemann-Pick disease type C. In less frequent diseases, such as those caused by mutations of SCAR18, the intensity of clinical presentation and ataxia depends on the transmission mode ${ }^{42}$. Spasticity is at the forefront of several other genetic diseases related to FOLR1, $C A P N 1, A F G 3 L 2$, and $S A C S^{43,47-52}$. Knowledge of these diseases and their identification are indispensable for providing specific treatment.

\section{Management of HSP}

\section{Magnetic resonance imaging and HSP diagnosis}

New neuroimaging findings allow precise HSP diagnosis on cerebral magnetic resonance imaging (MRI). For example, in SPG11, most patients have a thin corpus callosum ${ }^{54}$ and another sign is known as the "ear of the lynx" ${ }^{55}$. This sign corresponds to long $\mathrm{T} 1$ and $\mathrm{T} 2$ values in the forceps minor of the corpus callosum, which appears hyperintense on FLAIR (fluid-attenuated inversion recovery) and hypointense on T1-weighted images. Furthermore, new MRI techniques identified specific gray and white matter damage ${ }^{56}$. Neuropsychological exam and neuroimaging were performed on 25 SPG11 patients. This study allows us to describe a widespread pattern of damage in white matter probably linked to cognitive deficiency, described in this population, whereas progressive degeneration of multiple gray matter structures and spinal cord seems to be correlated with disease duration.

Another HSP well described by MRI is Pelizaeus-Merzbacher disease (L1CAM/SPG1-HSP). It is characterized by hypomyelination of brain stem and corticospinal tract on internal capsule $^{57}$. The hypomyelination underlines another overlap existing between HSP and leukodystrophies. Hypomyelinating disorders are observed in different genetic diseases. But the MRI pattern gives a clue to identify pathologies as Pelizaeus-Merzbacher disease, infantile GM1 and GM2 gangliosidosis, or fucosidosis ${ }^{58}$.

\section{Symptomatic treatment}

Symptomatic treatments for ataxia and HSP are complex and need long-term engagement from the patient and caregivers ${ }^{59}$. The first step is to implement rehabilitation therapies to preserve functions and develop compensations. Prevention of ataxia complications is necessary below the ataxia evolution. A multidisciplinary team for evaluation and management is essential to accompany patients over the long term at best and sometimes up to palliative care. For example, oropharyngeal dysphagia is a common symptom of the bulbar syndrome. It is one of the first symptoms in cerebellar ataxia which affect quality of life $\mathrm{e}^{60,61}$ and can lower life expectancy. It can occur in complications such as malnutrition, dehydration, and aspiration-related pneumonia. Therapy carried out by speech and language therapists has a positive significant outcome ${ }^{61}$. Another cerebellar symptom is the downbeat nystagmus. Different GABAergic substances, such as the 3,4-diaminopyridine and the 4-aminopyridine, have been tested. They have no major side effects and are well tolerated for a moderate success ${ }^{62}$. Baclofen is another GABAergic substance used against upbeat nystagmus.

Baclofen is also used in HSP as an oral anti-spastic. There are no specific therapies for the treatment of HSP. Treatment for spasticity of various origins is well recognized but does not follow national or international recommendations, as only a very small number of studies have evaluated symptomatic treatment ${ }^{63}$, in HSP. Studies from 2016 have evaluated oral anti-spastic treatment in children with cerebral palsy and concluded that randomized trials are needed ${ }^{64,65}$. Nonetheless, oral treatment such as levodopa has shown their efficacy on specific subgroups of HSP (SPG11 mimicking dopa-responsive dystonia and variant phenotype linked to $G C H 1$ mutations ${ }^{66,67}$. In addition to being treated by baclofen or levodopa, spasticity is treated by intramuscular injection with botulinum toxin type A. This treatment is recommended for focal spasticity as well as dystonic postures in many neurological diseases (e.g., multiple sclerosis $^{68}$ and cerebral palsy ${ }^{69}$ ). There has been only one retrospective study to evaluate the efficacy of combined treatment, consisting of botulinum toxin injection and intensive physical therapy for $\mathrm{HSP}^{70}$. Recruitment over five years included a small number of patients, including those with various genetic entities-SPG4 $\mathrm{n}=5$, SPG5 $\mathrm{n}=1$, SPG7 $\mathrm{n}=1$, SPG8 $\mathrm{n}=2$, SPG11 $\mathrm{n}=1, \operatorname{SPG} 72 \mathrm{n}=1$-and seven without a genetic diagnosis. All patients were given intramuscular injections of botulinum toxin followed by intensive physical therapy sessions (10 individualized sessions lasting two hours). After three months, they reported significantly reduced disease severity by the Spastic Paraplegia Rating Scale, reduced muscle tone (Modified Ashworth scale), and increased walking speed. However, they were unable to untangle the effect of injection from that of intensive physical therapy. Furthermore, there was no specific botulinum toxin injection protocol. The muscles injected, botulinum type, and administration of doses were left to the discretion of the physicians. This study also highlighted the difficulty of recruiting a large number of genetically and clinically homogenous patients. Several other symptomatic treatments have been tested and described through case reports or a cohort with very few patients. The treatments tested are, for instance, transcranial magnetic stimulation ${ }^{71}$, spinal cord stimulation $^{72}$, and specific rehabilitation $\operatorname{protocol}^{73}$.

HSP spasticity is a type of stiffness that emerges mainly during movement, such as walking or "catch and release" maneuvers. This aspect must be considered in establishing HSP-specific treatment for spasticity versus that for spasticity of any origin. At rest, spasticity is considerably reduced or absent, especially during the initial stages of the disease. This specific 
dynamic pattern is underlined by two findings: (i) dying back and regeneration of the corticospinal tract (high density of small fibers with thin myelin fibers found in SPG4) ${ }^{8}$ and/or (ii) a lack of coordination of cerebellar origin between agonist and antagonist muscles during movement. Such a lack of coordination was revealed by gait analysis of 23 HSP patients versus that of 23 controls $^{74}$. In that study, both knee and ankle muscles showed increased coactivity indices, and energetic parameters were higher for patients with HSP. The severity of the spasticity increased with coactivation, suggesting a lack of coordination: the abnormal activation of antagonist muscles obliged the agonist muscles to develop greater strength, resulting in spasticity.

There are only a few studies concerning how patients cope with their disease and the effectiveness of treatment from their point of view. One such study asked patients with HSP about their life with spasticity ${ }^{75}$. The patients felt ashamed of their disability and had difficulties tolerating their treatment. The symptoms of fatigue, depression, day-to-day fluctuations, and back pain ${ }^{76}$ are currently managed by patients but require more medical attention. A self-administered questionnaire completed six to eight times a day for a week by 35 patients with HSP showed that physical therapy and physical activity represented a very small proportion of their daily activities, and some reported no such activities despite their known usefulness against spasticity ${ }^{77}$.

Urinary and fecal disturbances, which are present and very frequent for $75 \%$ of patients with HSP, have been even less explored despite their recognized adverse impact on the quality of life of patients with $\mathrm{HSP}^{78}$. Women are more often affected than men $^{78}$. Furthermore, there have been no studies on fecal disturbances and their effect on spasticity. These difficulties are well described in Parkinson disease and multiple sclerosis $^{79,80}$, for example, but rarely in $\mathrm{HSP}^{81}$.

\section{Hope for a gene-specific therapy?}

No gene-specific therapy for HSP has been developed thus far, but physiopathological studies performed in animal models or neurons derived from induced pluripotent stem cells have provided potential therapeutic targets for some forms of HSP.

The first treatment trials took place for SPG5, an autosomal recessive HSP, caused by pathogenic variants in $C Y P 7 B 1$, which encodes oxysterol-7alpha-hydroxylase. This enzyme is involved in cholesterol degradation and leads to the accumulation of neurotoxic oxysterol (27-OH hydroxycholesterol) when altered $^{82}$. Two treatment trials have been carried out, both aiming to lower 27-hydroxycholesterol levels in patient serum as a read-out; they achieved the lowering of oxysterol levels but with no clinical benefit.

A replacement therapy was recently investigated by administrating CYP7B1 mRNA in a CYP7B1 knockout mouse model ${ }^{83}$. Forty-eight hours after the injection of mouse or human CYP7B1 mRNA, 25-hydroxycholesterol levels were considerably lower in the liver and serum and modestly lower in the brain, whereas 27-hydroxycholesterol levels were lower only in the serum. It was not possible to test whether this treatment was associated with an improvement in the motor phenotype as the CYP7B1 knockout mouse model does not show any obvious motor symptoms ${ }^{83}$. Impaired lipid metabolism has also been observed in a mouse model of SPG11, in which the accumulation of lipids in lysosomes has been shown to contribute to neurodegeneration. The absence of the SPG11 product, spatacsin, impairs cholesterol trafficking and leads to the accumulation of certain glycosphingolipids and gangliosides in lysosomes $^{84,85}$. Decreasing ganglioside levels using miglustat improved the motor phenotype in a SPG11 zebrafish model, suggesting that this could be a viable therapeutic strategy. However, miglustat poorly crosses the blood-brain barrier and it would be informative to test whether an alternative strategy to decrease ganglioside levels in the brains of Spg11 knockout mice can improve the motor or cognitive symptoms that have been observed $^{86}$. As SPG11 patients generally present their first symptoms before 10 years of age, it has been proposed that aside from neurodegeneration, altered brain development may contribute to the disease ${ }^{87}$. Consistent with this hypothesis, models derived from induced pluripotent stem cells of SPG11 patients show reduced proliferation of neuronal progenitors, impaired neurogenesis, and impaired neuronal differentiation ${ }^{88,89}$. These phenotypes have been shown to result from impaired GSK3 $\beta / \beta$-catenin signaling ${ }^{90}$. Tideglusib, a US Food and Drug Administration-approved GSK3 $\beta$ inhibitor, has been shown to restore the proliferation of neuronal progenitors and neuronal differentiation and correct the abnormal growth of SPG11 cortical organoids ${ }^{89-91}$. Tideglusib could thus be a therapy candidate for SPG11 patients, but its action on the developmental phase of the disease may preclude a beneficial effect in symptomatic patients. Preclinical and clinical studies are required to determine the efficacy of tideglusib as a therapy for SPG11 patients.

The product of SPG4, spastin, is a microtubule-severing protein. The downregulation of spastin or the expression of mutant spastin in Drosophila impairs locomotor performance and, at a subcellular level, leads to the stabilization of microtubules in synapses ${ }^{92}$. Treatment with the microtubule-targeting drug vinblastine reverts the synaptic phenotype in these Drosophila SPG4 models ${ }^{92}$. Similarly, neurons derived from Spg4 knockout mice show axonal swelling associated with impaired microtubule dynamics $^{83}$. Microtubule-targeting drugs, such as nocodazole, Taxol, or vinblastine, restore the pathological phenotype observed in Spg4-knockout neurons. Similar results have been obtained in neurons derived from induced pluripotent stem cells of SPG4 patients, supporting the idea that microtubule-targeting drugs could be of therapeutic interest for SPG4. However, this therapeutic strategy has yet to be translated into preclinical or clinical studies.

Spastin, together with atlastin-1 (SPG3) and REEP1 (SPG31), has been shown to play a role in linking microtubules to the endoplasmic reticulum (ER), thus controlling its shape ${ }^{94}$. 
Caenorhabditis elegans and Drosophila models of SPG4 also show signs of ER stress, and drugs known to modulate ER stress are able to improve motor symptoms in these animal models ${ }^{95}$. ER stress has also been observed in a Drosophila model of SPG31, and naringenin, a drug that protects cells from ER stress, is able to improve motor activity and life span in this model ${ }^{96}$. These studies highlight the role of ER stress as a potential mechanism that contributes to the physiopathology of HSP. ER stress could be used as a biomarker and therapeutic target for some forms of the disease. However, the presence of ER stress has thus far been observed only in invertebrate HSP models and has not yet been validated in mammalian models of SPG4 or SPG31 or in patients. This knowledge is critical before envisaging the targeting of ER stress as a therapeutic strategy.

These data show that physiopathological studies can lead to the identification of therapeutic strategies for various forms of HSP. However, the challenge will be to develop a specific treatment for each HSP subtype, given the large heterogeneity of these diseases. The alteration of ER stress in both SPG4 and SPG31 models suggests that common physiopathological mechanisms and thus common therapeutic targets could emerge, grouping several genetic subtypes. However, they will need to be validated in each subgroup of patients with HSP and will rely on the development of specific biomarkers. Rare diseases merit specific trials to develop new treatment strategies ${ }^{97}$, especially the use of homogeneous cohorts. There is a lack of natural history data, especially longitudinal biomarker analysis. To overcome these limitations, collaborative work with multinational cohorts is needed and identification of biomarkers should start.

\section{Conclusions}

The genetic heterogeneity of HSP is continuing to be unraveled by the discovery of new genes. Clear correlations between genotype and age at onset have been established, and a search for genetic or environmental modifiers will be necessary. Certain genes are shared between HSP and ataxias, and SPG7 is the leading example. For patients with a negative HSP panel result, genes responsible for other overlapping disorders need to be considered and after the testing for SPG4 exome sequencing is justified. In addition, pathological repeat expansion disorders could be ruled out.

The problem of heterogeneity also arises in studies on symptomatic treatment. Indeed, there is no consensus. Most studies have involved too few patients, sometimes with broad clinical and genetic heterogeneity, to allow global and generalizable conclusions. Thus, HSP is treated on the basis of the results of studies of other diseases without considering the characteristics of this population. This is particularly true in terms of spasticity. Indeed, HSP spasticity likely has a mechanism different from that of inflammatory diseases in particular. If the lack of coordination is at the origin of such spasticity, treatments must be rethought. This hypothesis strengthens the close links between HSP and spastic ataxia and opens up new avenues for the management of these diseases.
1. Parodi L, Fenu S, Stevanin G, et al.: Hereditary spastic paraplegia: More than an upper motor neuron disease. Rev Neurol (Paris). 2017; 173(5): 352-360. PubMed Abstract | Publisher Full Text

2. Kamate M, Detroja M: Clinico-Investigative Profile of Hereditary Spastic Paraplegia in Children. Ann Indian Acad Neurol. 2019; 22(3): 341-344. PubMed Abstract | Publisher Full Text | Free Full Text

3. Hellberg C, Alinder E, Jaraj D, et al:: Nationwide prevalence of primary dystonia progressive ataxia and hereditary spastic paraplegia. Parkinsonism Relat Disord. 2019; 69: 79-84. PubMed Abstract | Publisher Full Text

4. Ruano L, Melo C, Silva MC, et al.: The global epidemiology of hereditary ataxia and spastic paraplegia: A systematic review of prevalence studies. Neuroepidemiology. 2014; 42(3): 174-83. PubMed Abstract | Publisher Full Text

5. Coutinho $P$, Ruano L, Loureiro $\mathrm{JL}$, et al:: Hereditary ataxia and spastic paraplegia in Portugal: A population-based prevalence study. JAMA Neurol. 2013; 70(6): 746-55.

PubMed Abstract | Publisher Full Text

6. Omidvar ME, Torkamandi S, Rezaei S, et al:: Genotype-phenotype associations in hereditary spastic paraplegia: A systematic review and meta-analysis on 13,570 patients. J Neurol. 2019.

PubMed Abstract | Publisher Full Text

7. Bis-Brewer DM, Gan-Or Z, Sleiman P, et al.: Assessing non-Mendelian inheritance in inherited axonopathies. Genet Med. 2020; 22(12): 2114-2119. PubMed Abstract | Publisher Full Text | Free Full Text |

Faculty Opinions Recommendation
8. Parodi L, Fenu S, Barbier M, et al.: Spastic paraplegia due to SPAST mutations is modified by the underlying mutation and sex. Brain. 2018; 141(12): $3331-3342$.

3331-3342.
PubMed Abstract | Publisher Full Text

9. Svenson IK, Kloos MT, Gaskell PC, et al:: Intragenic modifiers of hereditary spastic paraplegia due to spastin gene mutations. Neurogenetics. 2004; $5(3)$ : 157-64.

PubMed Abstract | Publisher Full Text

10. McDermott CJ, Burness CE, Kirby J, et al:: Clinical features of hereditary spastic paraplegia due to spastin mutation. Neurology. 2006; 67(1): 45-51. PubMed Abstract | Publisher Full Text

11. S Shribman S, Reid E, Crosby AH, et al:: Hereditary spastic paraplegia: From diagnosis to emerging therapeutic approaches. Lancet Neurol. 2019; 18(12): 1136-1146.

PubMed Abstract | Publisher Full Text | Faculty Opinions Recommendation

12. Parodi L, Coarelli G, Stevanin G, et al.: Hereditary ataxias and paraparesias: Clinical and genetic update. Curr Opin Neurol. 2018; 31(4): 462-471. PubMed Abstract | Publisher Full Text

13. Casari G, Marconi R: Spastic Paraplegia 7. In: GeneReviews $₫$ [Internet]. Seattle (WA): University of Washington, Seattle, 1993-2021. Adam MP, Ardinger HH, Pagon RA, et al. (eds). 2006 PubMed Abstract

14. Atorino L, Silvestri L, Koppen M, et al.: Loss of $\boldsymbol{m}$-AAA protease in mitochondria causes complex I deficiency and increased sensitivity to oxidative stress in hereditary spastic paraplegia. J Cell Biol. 2003; 163(4): 777-87. PubMed Abstract | Publisher Full Text | Free Full Text 
15. Koppen M, Bonn F, Ehses S, et al:: Autocatalytic processing of $\boldsymbol{m}$-AAA protease subunits in mitochondria. Mol Biol Cell. 2009; 20(19): 4216-24. PubMed Abstract | Publisher Full Text | Free Full Text

16. Leonhard K, Guiard B, Pellecchia G, et al:: Membrane protein degradation by AAA proteases in mitochondria: extraction of substrates from either membrane surface. Mol Cell. 2000; 5(4): 629-38. PubMed Abstract | Publisher Full Text

17. Nolden M, Ehses S, Koppen M, et al.: The m-AAA protease defective in hereditary spastic paraplegia controls ribosome assembly in mitochondria. Cell. 2005; 123(2): 277-89.

PubMed Abstract | Publisher Full Text

18. Rugarli El, Langer $\mathrm{T}$ : Translating $m$-AAA protease function in mitochondria to hereditary spastic paraplegia. Trends Mol Med. 2006; 12(6): 262-9. PubMed Abstract | Publisher Full Text

19. Tatsuta $T$, Langer T: AAA proteases in mitochondria: Diverse functions of membrane-bound proteolytic machines. Res Microbiol. 2009; 160(9): 711-7. PubMed Abstract | Publisher Full Text

20. Karlberg $T$, van den Berg $S$, Hammarström M, et al.: Crystal structure of the ATPase domain of the human AAA+ protein paraplegin/SPG7. PLOS One. 2009; 4(10): e6975.

PubMed Abstract | Publisher Full Text | Free Full Text

21. Mancini $\mathrm{C}$, Hoxha E, lommarini L, et al:: Mice harbouring a SCA28 patient mutation in AFG3L2 develop late-onset ataxia associated with enhanced mitochondrial proteotoxicity. Neurobiol Dis. 2019; 124: 14-28. PubMed Abstract | Publisher Full Text | Faculty Opinions Recommendation

22. Pfeffer $\mathrm{G}$, Pyle A, Griffin $\mathrm{H}$, et al:: SPG7 mutations are a common cause of undiagnosed ataxia. Neurology. 2015; 84(11): 1174-6. PubMed Abstract | Publisher Full Text | Free Full Text

23. Coutelier M, Coarelli G, Monin ML, et al:: A panel study on patients with dominant cerebellar ataxia highlights the frequency of channelopathies. Brain. 2017; 140(6): 1579-1594

PubMed Abstract | Publisher Full Text

24. Coarelli G, Schule R, van de Warrenburg BPC, et al.: Loss of paraplegin drives spasticity rather than ataxia in a cohort of 241 patients with SPG7. Neurology. 2019; 92(23): e2679-e2690.

PubMed Abstract | Publisher Full Text | Free Full Text

25. Cupo M, Olivito G, Clausi S, et al:: Cerebello-Cortical Alterations Linked to Cognitive and Social Problems in Patients With Spastic Paraplegia Type 7: A Preliminary Study. Front Neurol. 2020; 11: 82 PubMed Abstract | Publisher Full Text | Free Full Text | Faculty Opinions Recommendation

26. Durr A: Autosomal dominant cerebellar ataxias: Polyglutamine expansions and beyond. Lancet Neurol. 2010; 9(9): 885-94. PubMed Abstract | Publisher Full Text

27. Chrestian N, Dupré N, Gan-Or Z, et al:: Clinical and genetic study of hereditary spastic paraplegia in Canada. Neurol Genet. 2017; 3(1): e122. PubMed Abstract | Publisher Full Text | Free Full Text

28. Kara E, Tucci A, Manzoni C, et al.: Genetic and phenotypic characterization of complex hereditary spastic paraplegia. Brain. 2016; 139(Pt 7): 1904-1918. PubMed Abstract | Publisher Full Text | Free Full Text

29. Coutelier M, Hammer MB, Stevanin G, et al:: Efficacy of Exome-Targeted Capture Sequencing to Detect Mutations in Known Cerebellar Ataxia Genes. JAMA Neurol. 2018; 75(5): 591-599.

PubMed Abstract | Publisher Full Text | Free Full Text

30. Choquet $\mathrm{K}$, Tétreault M, Yang S, et al.: SPG7 mutations explain a significant proportion of French Canadian spastic ataxia cases. Eur J Hum Genet. 2016; 24(7): 1016-1021.

PubMed Abstract | Publisher Full Text | Free Full Text

31. S Spagnoli $C$, Schiavoni S, Rizzi S, et al:: New biallelic GBA2 variant in a patient with SPG46. Clin Neurol Neurosurg. 2020; 191: 105676. PubMed Abstract | Publisher Full Text | Faculty Opinions Recommendation

32. Hammer MB, Eleuch-Fayache G, Schottlaender LV, et al:: Mutations in GBA2 cause autosomal-recessive cerebellar ataxia with spasticity. Am J Hum Genet. 2013; 92(2): 245-51.

PubMed Abstract | Publisher Full Text | Free Full Text

33. Citterio A, Arnoldi A, Panzeri E, et al.: Mutations in CYP2U1, DDHD2 and GBA2 genes are rare causes of complicated forms of hereditary spastic paraparesis. J Neurol. 2014; 261(2): 373-81.

PubMed Abstract | Publisher Full Text

34. Synofzik M, Hufnagel RB, Züchner S: PNPLA6- Related Disorders. In: GeneReviews $₫$ [Internet]. Seattle (WA): University of Washington, Seattle, 2014 [Updated 2015]: 1993-2021. Adam MP, Ardinger HH, Pagon RA, et al. (eds). PubMed Abstract

35. Synofzik M, Gonzalez MA, Lourenco CM, et al:: PNPLA6 mutations cause Boucher-Neuhauser and Gordon Holmes syndromes as part of a broad neurodegenerative spectrum. Brain. 2014; 137(Pt 1): 69-77. PubMed Abstract | Publisher Full Text | Free Full Text

36. Amador MDM, Masingue M, Debs R, et al:: Treatment with chenodeoxycholic acid in cerebrotendinous xanthomatosis: clinical, neurophysiological, and quantitative brain structural outcomes. J Inherit Metab Dis. 2018; 41(5): 799-807.

PubMed Abstract | Publisher Full Text

37. Nie S, Chen G, Cao X, et al:: Cerebrotendinous xanthomatosis: a comprehensive review of pathogenesis, clinical manifestations, diagnosis, and management. Orphanet J Rare Dis. 2014; 9: 179.

PubMed Abstract | Publisher Full Text | Free Full Text

38. Federico A, Dotti MT, Gallus GN: Cerebrotendinous Xanthomatosis. In GeneReviews ${ }^{\circledR}$. University of Washington, Seattle, Adam, M. P. et al. (eds). 1993 Reference Source

39. Cossée M, Dürr A, Schmitt M, et al:: Friedreich's ataxia: point mutations and clinical presentation of compound heterozygotes. Ann Neurol. 1999; 45(2): 200-206.

PubMed Abstract | Publisher Full Text

40. Pandolfo M, Arpa J, Delatycki MB, et al.: Deferiprone in Friedreich ataxia: 6-month randomized controlled trial. Ann Neurol. 2014; 76(4): 509-521. PubMed Abstract | Publisher Full Text

41. RTA 408 Capsules in Patients With Friedreich's Ataxia - MOXle. Full Text View - ClinicalTrials.gov. Reference Source

42. Nadjar $\mathrm{Y}$, Hütter-Moncada AL, Latour $\mathrm{P}$, et al.: Adult Niemann-Pick disease type $C$ in France: clinical phenotypes and long-term miglustat treatment effect. Orphanet J Rare Dis. 2018; 13(1): 175.

PubMed Abstract | Publisher Full Text | Free Full Text

43. Rossi M, Anheim M, Durr A, et al.: The genetic nomenclature of recessive cerebellar ataxias. Mov Disord. 2018; 33(7): 1056-1076. PubMed Abstract | Publisher Full Text

44. Coutelier M, Burglen L, Mundwiller E, et al:: GRID2 mutations span from congenital to mild adult-onset cerebellar ataxia. Neurology. 2015; 84(17): 1751-9.

PubMed Abstract | Publisher Full Text

45. De Michele G, Lieto M, Galatolo D, et al:: Spinocerebellar ataxia 48 presenting with ataxia associated with cognitive, psychiatric, and extrapyramidal features: A report of two Italian families. Parkinsonism Relat Disord. 2019; 65: 91-96.

PubMed Abstract | Publisher Full Text

46. Lieto M, Riso V, Galatolo D, et al:: The complex phenotype of spinocerebellar ataxia type 48 in eight unrelated Italian families. Eur J Neurol. 2020; 27(3): 498-505.

PubMed Abstract | Publisher Full Text

47. Tabassum S, AIAsmari A, AISaman AA: Widening the phenotypic spectrum - Non epileptic presentation of folate transporter deficiency. J Clin Neurosci. 2019; 59: 341-344

PubMed Abstract | Publisher Full Text | Faculty Opinions Recommendation

48. Steinfeld R, Grapp M, Kraetzner R, et al.: Folate receptor alpha defect causes cerebral folate transport deficiency: A treatable neurodegenerative disorder associated with disturbed myelin metabolism. Am J Hum Genet. 2009; 85(3): 354-63.

PubMed Abstract | Publisher Full Text | Free Full Text |

Faculty Opinions Recommendation

49. Wang Y, Hersheson J, Lopez D, et al.: Defects in the CAPN1 Gene Result in Alterations in Cerebellar Development and Cerebellar Ataxia in Mice and Humans. Cell Rep. 2016; 16(1): 79-91.

PubMed Abstract | Publisher Full Text | Free Full Text

50. Culli S, Del Bondio A, Baderna V, et al.: Pathogenic variants in the AFG3L2 proteolytic domain cause SCA28 through haploinsufficiency and proteostatic stress-driven OMA1 activation. J Med Genet. 2019; 56(8): 499-511.

PubMed Abstract | Publisher Full Text | Free Full Text | Faculty Opinions Recommendation

51. Synofzik M, Soehn AS, Gburek-Augustat J, et al:: Autosomal recessive spastic ataxia of Charlevoix Saguenay (ARSACS): Expanding the genetic, clinical and imaging spectrum. Orphanet J Rare Dis. 2013; 8: 41.

PubMed Abstract | Publisher Full Text | Free Full Text

52. SACS sacsin molecular chaperone [Homo sapiens (human)]. Gene - NCBI. National Center for Biotechnology Information. 2000. Reference Source

53. Stevanin G, Dürr A, Brice A: Clinical and molecular advances in autosomal dominant cerebellar ataxias: From genotype to phenotype and physiopathology. Eur J Hum Genet. 2000; 8(1): 4-18. PubMed Abstract | Publisher Full Text

54. Boutry M: Dysfonctions des lysosomes et neurodégénérescence : l'exemple de la paraplégie spastique de type SPG11. Neurosciences [q-bio.NC]. Universite Pierre et Marie Curie, 2017.

Reference Source

55. C Pascual B, de Bot ST, Daniels MR, et al:: "Ears of the Lynx" MRI Sign Is Associated with SPG11 and SPG15 Hereditary Spastic Paraplegia. AJNR Am J Neuroradiol. 2019; 40(1): 199-203.

PubMed Abstract | Publisher Full Text | Free Full Text |

Faculty Opinions Recommendation 
56. Faber I, Martinez ARM, de Rezende TJR, et al.: SPG11 mutations cause widespread white matter and basal ganglia abnormalities, but restricted cortical damage. Neuroimage Clin. 2018; 19: 848-857. PubMed Abstract | Publisher Full Text | Free Full Text | Faculty Opinions Recommendation

57. Sumida K, Inoue K, Takanashi Jl, et al.: The magnetic resonance imaging spectrum of Pelizaeus-Merzbacher disease: A multicenter study of 19 patients. Brain Dev. 2016; 38(6): 571-80

PubMed Abstract | Publisher Full Text

58. Steenweg ME, Vanderver A, Blaser S, et al:: Magnetic resonance imaging pattern recognition in hypomyelinating disorders. Brain. 2010; 133(10): 2971-82. PubMed Abstract | Publisher Full Text | Free Full Text

59. Cde Silva RN, Vallortigara J, Greenfield J, et al:: Diagnosis and management of progressive ataxia in adults. Pract Neurol. 2019; 19(3): 196-207. PubMed Abstract | Publisher Full Text | Free Full Text | Faculty Opinions Recommendation

60. Keage MJ, Delatycki MB, Gupta I, et al.: Dysphagia in Friedreich Ataxia. Dysphagia. 2017; 32(5): 626-635. PubMed Abstract | Publisher Full Text

61. Speyer R, Baijens L, Heijnen M, et al.: Effects of therapy in oropharyngeal dysphagia by speech and language therapists: A systematic review. Dysphagia. 2010; 25(1): 40-65.

PubMed Abstract | Publisher Full Text | Free Full Text

62. Kalla R, Teufel J, Feil K, et al.: Update on the pharmacotherapy of cerebellar and central vestibular disorders. J Neurol. 2016; 263 Suppl 1: S24-9. PubMed Abstract | Publisher Full Text | Free Full Text

63. Bellofatto M, de Michele G, lovino A, et al:: Management of Hereditary Spastic Paraplegia: A Systematic Review of the Literature. Front Neurol. 2019; 10: 3

PubMed Abstract | Publisher Full Text | Free Full Text | Faculty Opinions Recommendation

64. Koy A, Lin JP, Sanger TD, et al:: Advances in management of movement disorders in children. Lancet Neurol. 2016; 15(7): 719-735. PubMed Abstract | Publisher Full Text

65. Navarrete-Opazo AA, Gonzalez W, Nahuelhual P: Effectiveness of Oral Baclofen in the Treatment of Spasticity in Children and Adolescents With Cerebral Palsy. Arch Phys Med Rehabil. 2016; 97(4): 604-18. PubMed Abstract | Publisher Full Text

66. Wijemanne S, Shulman JM, Jimenez-Shahed J, et al:: SPG11 Mutations Associated With a Complex Phenotype Resembling Dopa-Responsive Dystonia. Mov Disord Clin Pract. 2015; 2(2): 149-54 PubMed Abstract | Publisher Full Text | Free Full Text

67. Wassenberg T, Schouten MI, Helmich RC, et al:: Autosomal dominant GCH1 mutations causing spastic paraplegia at disease onset. Parkinsonism Relat Disord. 2020; 74: 12-15.

PubMed Abstract | Publisher Full Text | Faculty Opinions Recommendation

68. Safarpour Y, Mousavi T, Jabbari B: Botulinum Toxin Treatment in Multiple Sclerosis-a Review. Curr Treat Options Neurol. 2017; 19(10): 33 PubMed Abstract | Publisher Full Text

69. Graham HK, Aoki KR, Autti-Rämö I, et al:: Recommendations for the use of botulinum toxin type A in the management of cerebral palsy. Gait Posture. 2000; 11(1): 67-79.

PubMed Abstract | Publisher Full Text

70. P Paparella G, Vavla M, Bernardi L, et al.: Efficacy of a Combined Treatment of Botulinum Toxin and Intensive Physiotherapy in Hereditary Spastic Paraplegia. Front Neurosci. 2020; 14: 111. PubMed Abstract | Publisher Full Text | Free Full Text | Faculty Opinions Recommendation

71. Antczak J, Pera J, Dąbroś M, et al:: The Effect of Repetitive Transcranial Magnetic Stimulation on Motor Symptoms in Hereditary Spastic Paraplegia. Neural Plast. 2019; 2019: 7638675

PubMed Abstract | Publisher Full Text | Free Full Text |

Faculty Opinions Recommendation

72. Ardolino G, Bocci T, Nigro M, et al.: Spinal direct current stimulation (tsDCS) in hereditary spastic paraplegias (HSP): A sham-controlled crossover study. $J$ Spinal Cord Med. 2018; 1-8.

PubMed Abstract | Publisher Full Text | Faculty Opinions Recommendation

73. Sato M, Kannari K, Tomari M, et al.: Physical therapy intervention with a low frequency of exercise for a patient with a complicated form of hereditary spastic paraplegia: A case report. J Phys Ther Sci. 2019; 31(7): 545-549. PubMed Abstract | Publisher Full Text | Free Full Text |

Faculty Opinions Recommendation

74. Rinaldi M, Ranavolo A, Conforto S, et al:: Increased lower limb muscle coactivation reduces gait performance and increases metabolic cost in patients with hereditary spastic paraparesis. Clin Biomech (Bristol, Avon). 2017; 48: $63-72$.

PubMed Abstract | Publisher Full Text

75. Kerstens HCJW, Satink T, Nijkrake MJ, et al:: Stumbling, struggling, and shame due to spasticity: A qualitative study of adult persons with hereditary spastic paraplegia. Disabil Rehabil. 2019; 42(26): 3744-3751.

PubMed Abstract | Publisher Full Text | Faculty Opinions Recommendation

76. Servelhere KR, Faber I, Saute JAM, et al:: Non-motor symptoms in patients with hereditary spastic paraplegia caused by SPG4 mutations. Eur J Neurol. 2016; 23(2): 408-11.

PubMed Abstract | Publisher Full Text

77. Sartori RDG, Marelli M, D'Angelo MG, et al:: Autonomy level and quality of everyday experience of people with Hereditary Spastic Paraplegia. Health Soc Care Community. 2019; 27(5): e850-e860.

PubMed Abstract | Publisher Full Text | Faculty Opinions Recommendation

78. Schneider SA, Beckinger VE, Möller B, et al.: Urinary symptoms, quality of life, and patient satisfaction in genetic and sporadic hereditary spastic paraplegia. J Neurol. 2019; 266(1): 207-11.

PubMed Abstract | Publisher Full Text | Faculty Opinions Recommendation

79. Phé V, Chartier-Kastler E, Panicker JN: Management of neurogenic bladder in patients with multiple sclerosis. Nat Rev Urol. 2016; 13(5): 275-88. PubMed Abstract | Publisher Full Text

80. Sakakibara R, Panicker J, Finazzi-Agro E, et al:: A guideline for the management of bladder dysfunction in Parkinson's disease and other gait disorders. Neurourol Urodyn. 2016; 35(5): 551-63. PubMed Abstract | Publisher Full Tex

81. Rattay TW, Boldt A, Völker M, et al:: Non-motor symptoms are relevant and possibly treatable in hereditary spastic paraplegia type 4 (SPG4). J Neurol. 2020; 267(2): 369-379.

PubMed Abstract | Publisher Full Text | Faculty Opinions Recommendation

82. Schöls L, Rattay TW, Martus $\mathrm{P}$, et al:: Hereditary spastic paraplegia type 5: natural history, biomarkers and a randomized controlled trial. Brain. 2017; 140(12): 3112-3127.

PubMed Abstract | Publisher Full Text | Free Full Text

83. H Hauser $\mathrm{S}$, Poenisch M, Schelling $\mathrm{Y}$, et al:: mRNA as a Novel Treatment Strategy for Hereditary Spastic Paraplegia Type 5. Mol Ther Methods Clin Dev. 2019; 15: 359-370.

PubMed Abstract | Publisher Full Text | Free Full Text | Faculty Opinions Recommendation

84. Boutry M, Branchu J, Lustremant C, et al:: Inhibition of Lysosome Membrane Recycling Causes Accumulation of Gangliosides that Contribute to Neurodegeneration. Cell Rep. 2018; 23(13): 3813-3826. PubMed Abstract | Publisher Full Text | Free Full Text

85. Boutry M, Morais S, Stevanin G: Update on the Genetics of Spastic Paraplegias. Curr Neurol Neurosci Rep. 2019; 19(4): 18. PubMed Abstract | Publisher Full Text | Faculty Opinions Recommendation

86. Branchu J, Boutry M, Sourd L, et al.: Loss of spatacsin function alters lysosomal lipid clearance leading to upper and lower motor neuron degeneration. Neurobiol Dis. 2017; 102: 21-37.

PubMed Abstract | Publisher Full Text | Free Full Text

87. Pozner T, Regensburger M, Engelhorn T, et al.: Janus-faced spatacsin (SPG11): Involvement in neurodevelopment and multisystem neurodegeneration. Brain. 2020; 143(8): 2369-2379. PubMed Abstract | Publisher Full Text | Free Full Text | Faculty Opinions Recommendation

88. Pérez-Brangulí F, Mishra HK, Prots I, et al:: Dysfunction of spatacsin leads to axonal pathology in SPG11-linked hereditary spastic paraplegia. Hum Mol Genet. 2014; 23(18): 4859-74 PubMed Abstract | Publisher Full Text | Free Full Text

89. Dérez-Brangulí F, Buchsbaum IY, Pozner T, et al:: Human SPG11 cerebra organoids reveal cortical neurogenesis impairment. Hum Mol Genet. 2019; 28(6): 961-71.

PubMed Abstract | Publisher Full Text | Free Full Text | Faculty Opinions Recommendation

90. Mishra HK, Prots I, Havlicek S, Kohl Z, et al.: GSK3ß-dependent dysregulation of neurodevelopment in SPG11-patient induced pluripotent stem cell model. Ann Neurol. 2016; 79(5): 826-840.

PubMed Abstract | Publisher Full Text | Free Full Text

91. Pozner T, Schray A, Regensburger M, et al:: Tideglusib Rescues Neurite Pathology of SPG11 iPSC Derived Cortical Neurons. Front Neurosci. 2018; 12 Patholo PubMed Abstract | Publisher Full Text | Free Full Text | Faculty Opinions Recommendation

92. Orso G, Martinuzzi A, Rossetto MG, et al.: Disease-related phenotypes in a Drosophila model of hereditary spastic paraplegia are ameliorated by treatment with vinblastine. J Clin Invest. 2005; 115(11): 3026-34. PubMed Abstract | Publisher Full Text | Free Full Text

93. Fassier $\mathrm{C}$, Tarrade $\mathrm{A}$, Peris $\mathrm{L}$, et al:: Microtubule-targeting drugs rescue axonal swellings in cortical neurons from spastin knockout mice. Dis Model Mech. 2013; 6(1): 72-83 PubMed Abstract | Publisher Full Text | Free Full Text

94. Park SH, Blackstone $\mathrm{C}$ : Further assembly required: Construction and dynamics of the endoplasmic reticulum network. EMBO Rep. 2010; 11(7): 515-21. PubMed Abstract | Publisher Full Text | Free Full Text 
95. Julien C, Lissouba A, Madabattula S, et al.: Conserved pharmacological rescue of hereditary spastic paraplegia-related phenotypes across model organisms. Hum Mol Genet. 2016; 25(6): 1088-99.

PubMed Abstract | Publisher Full Text | Free Full Text

96. Napoli B, Gumeni S, Forgiarini A, et al.: Naringenin Ameliorates Drosophila ReepA Hereditary Spastic Paraplegia-Linked Phenotypes. Front Neurosci.
2019; 13: 1202.

PubMed Abstract | Publisher Full Text | Free Full Text |

Faculty Opinions Recommendation

97. Durr A: Rare inherited diseases merit disease-specific trials. Lancet Neurol. 2015; 14(10): 968-9.

PubMed Abstract | Publisher Full Text 